$$
\text { 小腸間膜内ヘルニアの } 1 \text { 例 }
$$

八木公立尾陽病院外科

症例は48歳の女性で, 2006年 1 月初旬に腹痛，湢吐，下痢が出現したため当院を受診 した。右下腹部に軽度圧痛を認めたが, 腹膜刺激症状は認めなかった。腹部単純 X 線・ 腹部 CT でイレウス像を呈しており，イレウス管を挿入し保存的治療を開始した．イレ ウス管造影で右下腹部に回腸の狭窄部を認め, 内ヘルニアを疑って入院 9 日目に開腹術 を施行した．回腸末端より約 $2 \mathrm{~m}$ 口側の回腸が回腸終末部背側の腸間膜に Richter 型に

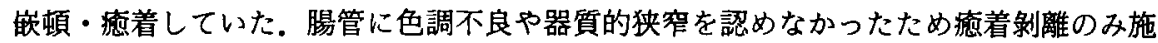
行した. 剩㒕後に観察すると小腸間膜後葉に $3.5 \times 2.0 \mathrm{~cm}$ の欠損部を認めたが, 前葉には 穿通していなかった。腸間膜欠損部は縫合閉鎖した. 手術所見から Richter 型の小腸間膜 内ヘルニアと診断した。術後経過は良好で, 術翌日より経口摄取を開始し術後 8 日目に 軽快退院した.

索引用語：腸間膜内ヘルニア, 内ヘルニア，イレウス

\section{緒 言}

内ヘルニアは腹腔内の異常裂孔や腹膜窩に腹部臟器 が嵌入することによって生じる比較的稀な疾思で，そ の多くはイレウスで発症する，今回，われわれは内へ ルニアの1つである腸間膜裂孔ヘルニアのなかでも極 めて稀な小腸間膜内へルニアを経験したので若干の文 献的考察を加えて報告する.

$$
\text { 症例 }
$$

症例：48歳, 女性.

主訴：腹痛, 嘔吐, 下痢.

既往歴：特記すべきことなし。開腹手術歴, 外傷歷 なし.

家族歴：特記すべきことなし。

現病歴：2006年 1 月初旬の夕刻より腹痛が出現し, その後哣吐・下痢も出現したため翌日午前 4 時に当院 救急外来を受診した.

入院時現症: 身長 $150 \mathrm{~cm}$, 体重 $49.2 \mathrm{~kg}$, 血圧 $120 / 50$ $\mathrm{mmHg}$, 脈拍 100 回/分・整, 体温 $37.2^{\circ} \mathrm{C}$. 腹部は軽度 臌満し, 右下腹部に軽度圧痛を認めたが, 反跳痛, 筋 性防御は認めなかった。

2006年 5 月12日受付 2006年 6 月21日採用

〈所属施設住所〉 $\mathrm{T} 490-1111$

要知県海部郡甚目寺町大字甚目寺字山八浦 148
入院時血液検查所見：白血球 $17,030 / \mu 1$, 血糖 352 $\mathrm{mg} / \mathrm{dl}$ と上昇を認めた。その他は異常所見を認めなか った.

入院時腹部単純 $\mathrm{X}$ 線検査：小腸ガスの貯留と鏡面 像を認めた（図 1 )。

入院時腹部 CT 検査 : 上腹部優位に小腸は抎張し, 回盲部は盲腸主体の壁肥厚と周囲脂肪吸収値上昇を認 め, 炎症性変化が疑われた。他に少量の腹水を認めた (図 2).

入院後経過：以上より，イレウスと診断し絶飲食と した．原因として典型的てはないが，回盲部の腸重積 や虫垂炎・香室炎などの炎症性疾患を考慮した。ガス トログラフィンで注腸検查を回腸末端より口側約 $1 \mathrm{~m}$ の回腸まで施行した，腫瘍性病変, 結腸款室, Meckel 想室, 腸重積を示唆する所見は得られず，狭窄部の確 認はできなかった。また虫垂も造影されたため虫垂炎 は否定的であった，絞抳性イレウスには至っていない と判断してイレウス管を挿入し保存的治療を開始し た。血液検査上，白血球や入院翌日に $3.4 \mathrm{mg} / \mathrm{dl}$ まで上 昇していた CRP の炎症所見は改善したが，イレウス は改善しなかったため，イレウス管より造影㭘査を施 行した.

イレウス管造影検査：入院 7 日目のイレウス管造影 で，右下腹部に回腸の狭窄部を認めた（図 3 ）。 


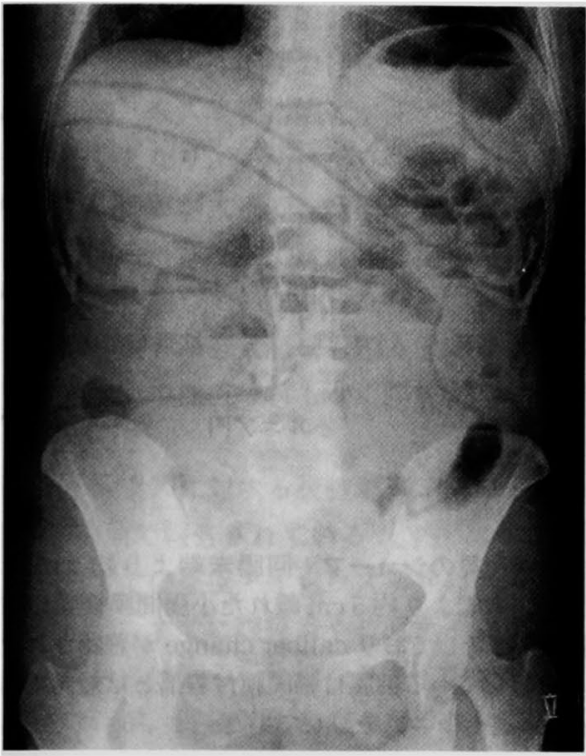

図 1 腹部単純 $\mathbf{X}$ 線検査：小腸ガスの貯留と鏡 面像を認める。

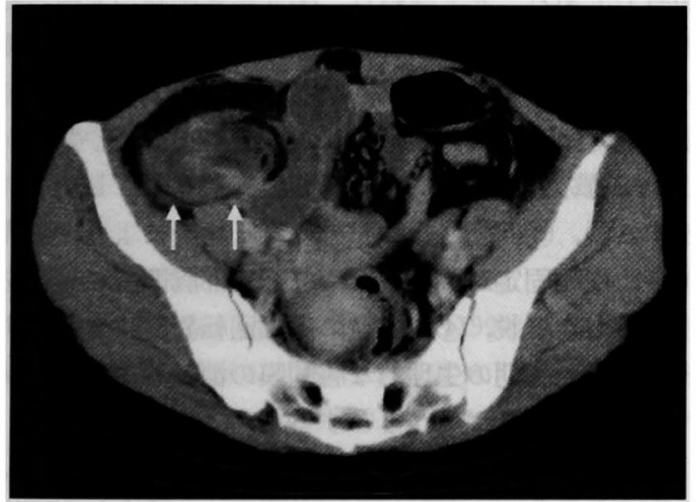

図 2 腹部造影 CT 検査：小腸は抎張し, 回盲部は盲腸 主体の壁肥厚と周囲脂肪吸収值上昇を認める。

以上より,保存的治療では解除されないイレウスで, 原因として開腹手術歴がないことから内へルニア，特 に盲腸周囲ヘルニアを疑って入院 9 日目に開腹術を施 行した.

手術所見：イレウスの原因を検索すると，回腸が， 末端より約 $2 \mathrm{~m}$ 口側で回腸終末部背側の腸間膜に嵌 頓・癒着しており caliber change を確認した。また嵌 頓・痣着している回腸は腸間膜付着部とは対側で，嵌 入部分は約 $4 \mathrm{~cm}$ であった（図 $4 \mathrm{a}$ ）。軽い牽引のみで 脑張腸管から狭窄腸管に内腔のガスが移動することが

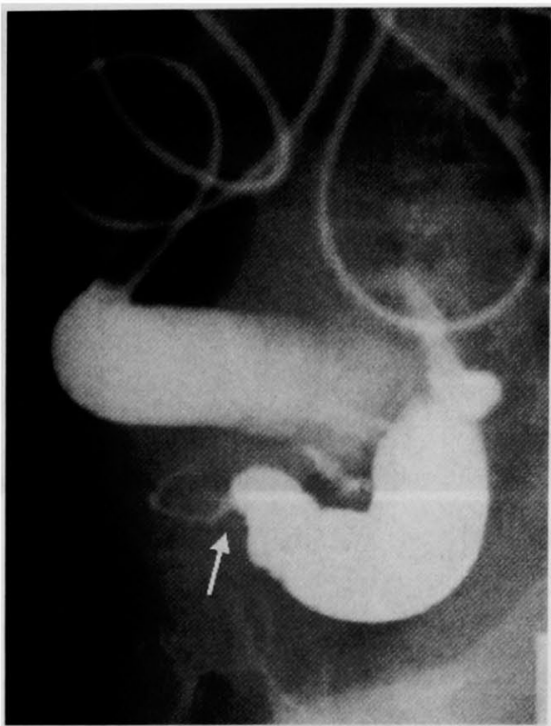

図 3 イレウス管造影検査：右下腹部で回腸 の狭窄部を認める。

確認され，腸管に色調不良や器質的狭窄を認めなかつ たため癒着剝離のみ行い，イレウスを解除した。剥離 後に癒着部を観察すると回腸末端より約 $5 \mathrm{~cm}$ 離れた 小腸間膜後葉に $3.5 \times 2.0 \mathrm{~cm}$ の辺縁平滑な卵円型の欠 損部を認めへルニア門となっていた，前葉には通じて いなかった(図 4 b)）へルニア門を縫合閉鎖し，イレ ウス管は可及的に腸管を隇圧した後に抜去した。

手術所見から Richter 型を呈した回腸終末部の小腸 間膜内ヘルニアと診断した（図 5 )。

術後経過：経過良好で手術翌日より経口摄取を開始 し，術後 8 日目に軽快退院した。

\section{考 察}

内ヘルニアは腹啌内の生理的あるいは先天的な裂孔 や腹膜窩に腹部臟器が入り込むことにより生じ，裂孔 を介する異常裂孔へルニア，腹膜窩を介する腹膜窩へ ルニアに大別され，その多くはイレウス症状をきたす ものである"．イレウス全体の原因として内へルニア は0.01〜 $5 \%$ 程度で，そのうち腹膜䆟へルニアが約 40 $\%$, 異常裂孔へルニアが約 $60 \%$ とされている21.内へル ニアの発生部位は多岐にわたり, 渡部ら ${ }^{3)}$ の本邦での 報告453例の集計では13力所に及び，118例の大網裂孔 ヘルニアと109例の傍十二指腸ヘルニアが多いと報告 しているが，腸間膜ヘルニアも，結腸と小腸を併せて 考慮すると108例と多い.

腸間膜裂孔ヘルニアは，腸間膜の異常裂孔に腸管が 


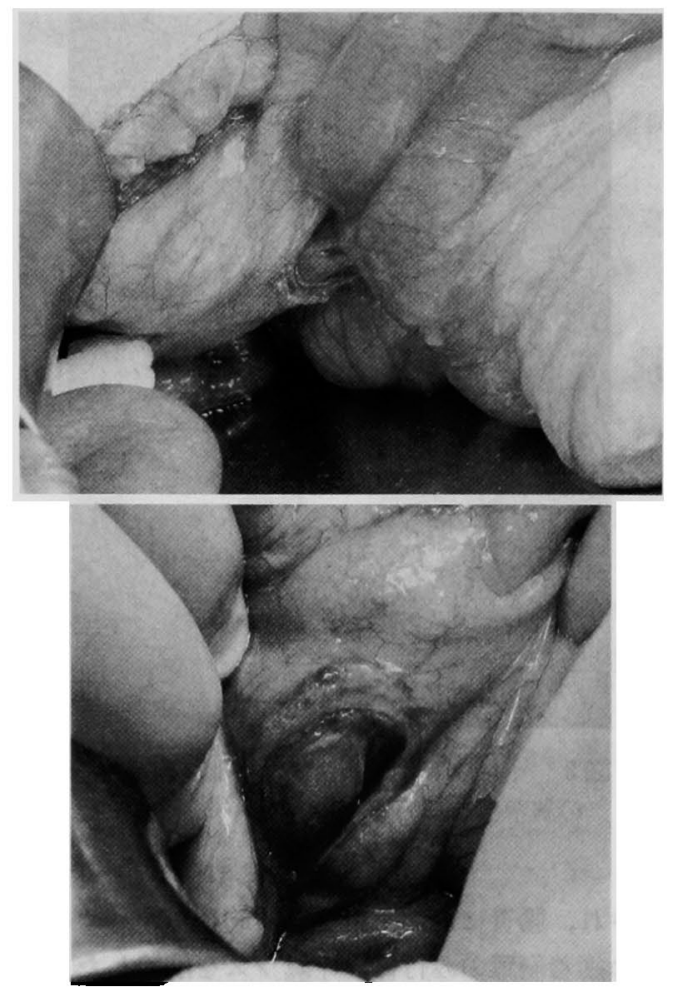

図 4 手術所見：a）回腸が回腸終末部背側の腸間 膜に嵌頓・痹着しており，嵌頓・應着している回腸 は腸間膜付着部とは対側である。 b ) 小晹間膜後葉 に3.5 $\times 2.0 \mathrm{~cm}$ の辺緑平滑な卵円型の欠損部を認め る. 前葉には通じていない.

嵌入する異常裂孔へルニアに分類され，結腸間膜や小 腸間膜で発生する．堀ら゙の本邦200例の集計では小腸 間膜裂孔へルニアが138例, 結腸間膜裂孔ヘルニアが62 例と報告している．腸間膜裂孔へルニアは，ヘルニア 襄をもたない経腸間膜ヘルニアとヘルニア慗をもつ腸 間膜内へルニアに分類して考虑されている5. 本症例 は, 小腸間膜欠損部が穿通せずに対側の腹膜が存在し 腸間膜自体がヘルニア襄になっており腸間膜の間に腸 管が嵌入していたため小腸間膜内へルニアに分類され る. 医学中央雑誌 (1983年以降)で検索した範囲では, 腸間膜内ヘルニアの報告は $\mathrm{S}$ 状結腸によるものが多 $く^{6)}$, 他には 1 例の小腸間膜内ヘルニアラを認めるのみ であり，本症例のように小腸間膜で欠損部が穿通せず に対側の腹膜が存在することは極めて稀であると考え る.

裂孔の成因として，先天説と外傷や炎症を契機に発

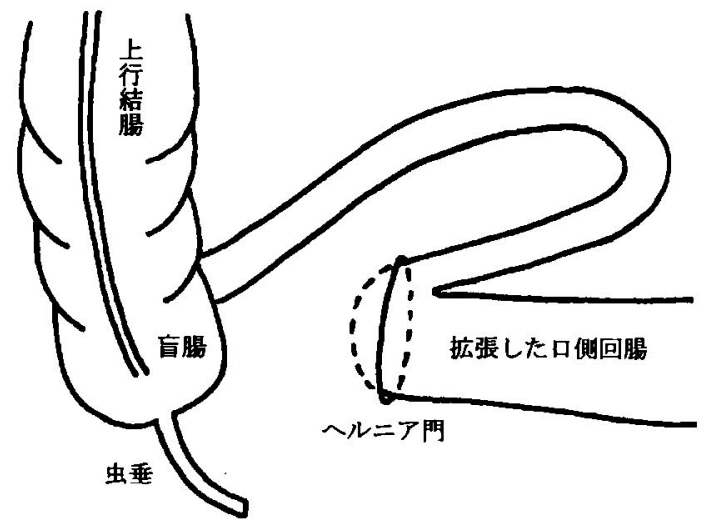

図 5 手術所見のシェーマ：回腸末端より約 $2 \mathrm{~m}$ 口側の 回腸が，末端より䄪 $5 \mathrm{~cm}$ 離れた小腸間膜後葉の欠損部 に嵌頓・瘾着しており caliber change が確認された。嵌 頓・㾌着している回腸は腸間膜付着部とは対側であり, Richter 型ヘルニアを呈していた。

生する後天説がある。しかし, 多くは裂孔辺縁が平滑 で炎症を認めず, 外傷などの既往もないため, 先天説 が有力である. 先天説には, (1)回結腸動脈が欠損した 場合, 回結腸動脈・右結腸動脈間の脆弱な腸間膜に裂 孔を生じるとする説, (2)回結腸動脈と終末小腸枝との 疮合部は脂肪組織，血管，リンパ管が欠損しやすく， この部位の抵抗性が低下し陽間膜穿孔をおこしやすい とする説, (3)回腸と腸間膜の発育不均衡により, 腸間 膜の二次的固定が不充分となり回盲部腸間膜に裂孔を 生じるとする説，(4)胎生期の内缄回転異常によるとす る説, (5)胎生期の生理的な腸間膜の消滅現象が強く現 れたときに裂孔が生じるとする説，などがある(7) 99. また裂孔の存在部位は回腸終末部に多く，信原ら ${ }^{8)}$ は， 上記(1)(2)(3)の説を虽付けるとしている. 本症例では, 外傷・手術の既往はないことから先天説が考えられ, 手術時に内臓回転異常がないことや回結腸動脈の存在 が確認されておう，成因として上記(1)(4)は否定できる.

一般に内へルニアの術前診断は困難とされ, 最近で は, イレウス管からの造影, CT などの画像診断が有用 とされている(10) 13)が，いまだ手術によって診断がつく ことが多い.本症例でも開腹手術歴のないイレウスで, 種々の疾患を除外して右下腹部での内へルニアを起こ す盲腸周囲へルニアを疑ったが術前の確定診断には至 らなかった. Richter 型ヘルニアで嵌入腸管が短かっ たことも診断を困難にした要因と考えられ，手術歴が あれば携着性イレウスとの鑑別はさらに難しいものと なっていたと想像される。 
内ヘルニアの治療は，一般的にイレウスの診断で手 術されることが多い. 手術では嵌入腸管の整復, ヘル ニア門の閉銷，嵌入腸管に壊死が認められる場合は腸 管切除が必要となり，手術に踏み切るタイミングを常 に念頭におくことが大事で，時期を失しないように対 処すべきである．本症例では，腸間膜対側の腹膜が存 在し欠損部が穿通していなかったため, 腸管が入り込 むスペースがなく，嵌入腸管も短く Richter 型を呈し ていたため腸管の血流障害もなく腸管切除を必要とし なかった.

近年，イレウスに対する腹腔鏡下手術の有効性が診 断・治療の両面で報告されている(4).内へルニアにおい ても腹胫鏡下での整復・イレウス解除の報告例が散見 される3115) 17).すで腹膜炎や絞扼性イレウスを起こ している場合には緊急手術となり多くの場合, 腹腔鏡 の適応はないが，待機的に治療を行う際には内へルニ アの種類とその部位を術前に知っておくことは，今後 は增加してくることが予想される腹腔鏡下手術におい ては重要になってくると考える。

\section{結 語}

腸間膜裂孔へルニアのなかでも極めて稀な小腸間膜 内ヘルニアを経験した．原因の明らかでないイレウス に遭遇した際には内へルニアの可能性を念頭において 時期を失することなく診断・治㞠にあたる必要がある。

\section{文献}

1）小沢邦寿：内へルニア. 森岡恭彦編，新臨床外科 学, 第 3 版, 医学書院, 東京, 1999, p424

2）角南栄二，鈴木 聡，三科 武他：横行結腸間膜 裂孔へルニアの1例. 日消外会誌 $37 ： 1491-$ 1496, 2004

3）渡部通章, 三森教雄, 志田敦男他：腹腔鏡下に整 復した $\mathrm{S}$ 状結腸間膜内へルニア，日消外会誌 $36: 309-313,2003$

4）堀 智英, 村林紘二, 赤坂義和他：絞扼性イレウ スを生じた成人の小腸間膜裂孔へルニアの 1 例一 本邦報告138例の検討一. 三重医 $45: 99-104$, 2002
5）佐藤秀一, 竹山信之, 吉田啺元他：内へルニアの CT 診断. 画像診断 $25: 1034-1049,2005$

6) 秋山有史, 青木毅一, 中屋 勉他：S 状結腸間膜内 ヘルニアによるイレウスの1例。日消外会誌 37 : 1781-1786, 2004

7）田畑智丈, 森浦滋明, 小林一郎他：高龄者におけ る小腸腸間膜裂孔へルニア嵌頓による絞拒性イレ ウスの1例. 日臨外会誌 $62: 221-224,2001$

8）信原宏礼, 横山雄二郎：小腸腸間膜裂孔ヘルニア 嵌頓による皎扼性イレウスの 1 例。広島医 55 ： $409-411,2002$

9）豊田啺彦，野坂仁愛，若月俊郎他：小児腸間膜裂 孔ヘルニアの 1例. 鳥取医誌 $31: 70-73,2003$

10）五十嵐章，奥田康一，西脇 真他：術前診断しえ た S 状結腸問膜内ヘルニアの 1 例. 日消外会誌 $31: 1816-1820,1998$

11）小林昭彦，小関廣明，増子 毅他：術前診断に小 腸造影検查が有効であった内ヘルニアの 2 例. 日 消外会誌 $33: 634-638,2000$

12）金子 猛, 西平友彦, 㫮田昌信他：䛦断にCT が 有用であった甾腸後窝へルニアのI例．日臨外会 誌 $64: 2217-2220,2003$

13）山下久幾, 勝部隆男, 今野宗一他：マルチスライ スCTが診断に有用上考えられた下回盲窝へルニ アの1例。日臨外会誌 $66: 2730-2733,2005$

14）鈴木憲次，木村泰三：イレウスに対する腹腔鏡下 手術の適応と限界.カレントテラピー $23: 885-$ 888,2005

15）丸山浩高，三尾寿樹，高木大志他：腹腔鏡補助下 に根治術を行った S 状結腸間膜简へルニアの 1 例. 日臨外会誌 $66: 2033-2037 ， 2005$

16）堺浩太郎，藤木健弘，倉持 均他：腹腔鏡下に治 療した盲腸後简へルニアの1例. 日臨外会誌 $65: 718-721,2004$

17）米满弘一郎, 鶴田 豊, 外山栄一郎他：腹腔鏡下 に䛦断・解除しえた超高齢者盲腸周囲ヘルニア嵌 頓の 1 例。外科 $67: 1344-1346,2005$ 


\title{
A CASE OF SMALL INTESTINAL INTRAMESENTERIC HERNIA
}

\author{
Yoshikazu YAGI, Kiyotsugu TAKAHASHI, Naoto OKUDA and Kenji ICHIKAWA \\ Department of Surgery, Biyo Public Hospital
}

A 48-year-old woman was seen at the hospital because of abdominal pain, vomiting and diarrhea in January 2006. There was mild tenderness in the right lower quadrant of abdomen without peritoneal stimulating signs. Abdominal X-ray and CT scan showed small intestinal gas and fluid image. We diagnosed the case as small intestinal obstruction, and conducted conservative therapy using a long tube. Radiological study via the long tube with contrast agent showed stenosis of the ileum at the right lower abdominal region. Internal hernia was suspected and surgery was carried out on the $9^{\text {th }}$ hospital day. Incarceration and adhesion of the ileum were found about $2 \mathrm{~m}$ proximal from the terminal ileum into a posterior mesenteric defect of the ileum. The adhesion was loosened because the impacted ileum was not necrotic and stenotic. The oval defect, $3.5 \times 2.0 \mathrm{~cm}$ in diameter, was observed in the posterior mesentery of the ileum and did not penetrate into the anterior one. Its defect was closed with sutures. Operative findings clarified the diagnosis of small intestinal intramesenteric hernia of Richter's type. The postoperative course was uneventful and she was discharged 8 days after the operation. 